\title{
PERANAN PENYULUH AGAMA HINDU DALAM MENGIMPLEMENTASIKAN AJARAN TRI HITA KARANA BAGI MASYARAKAT KABUPATEN TABANAN
}

\author{
Ni Wayan Silawati. \\ Widyaiswara Ahli Utama \\ Balai Diklat Keagamaan Denpasar \\ Email: Niwayansilawati12@gmail.com
}

(Received: tgl-bln-thn; Reviewed: tgl-bln-thn; Revised: tgl-bln-thn; Accepted: tgl-bln-thn; Published: tgl-bln-thn)

\begin{abstract}
Problems occured not only because of people selfishness or greediness, but also the lack of understanding about Tri Hita Karana concept in the community. According to Decision of Minister of Religion No. 516 the role of adviser of awareness-raising program to guide and foster community in the religious way. It is notable for the adviser of such program to understand the existing problems by providing education and better understanding of Tri Hita Karana Concept. Nonetheless the understanding and practice of Tri Hita Karan for the adviser of Hindu Religion? This issue is raised so we have visibility about the understanding and practice of Tri Hita Karan by adviser of Hindu Religion. The topic had been researched using qualitative method, gathering data by interview with the source, located in Ministry of Religion Tabanan Regency. Based on the research result, it was stated that the method which used to explain the concept of Tri Hita Karana is not good enough. The Adviser is recommended to improve the competency of advising, especially the method and strategy of advising. Therefore, according to KMA No. 516, Religious Training Centre have a duty to give training to advisers.
\end{abstract}

Keywords: Tri Hita Karana, Hinduism Counsellor.

\begin{abstract}
ABSTRAK
Permasalahan terjadi bukan karena egoisme atau materi semata, namun kurangnya pemahaman mengenai konsep Tri Hita Karana yang kurang dalam masyarakat. Berdasarkan Keputusan Menteri Agama Nonor 516 peran penyuluh untuk membimbing dan membina masyarakat dengan bahasa agama. Maka penting bagi penyuluh, untuk memahami permasalahan yang ada dengan memberikan pendidikan dan pemahaman konsep Tri Hita Karana. Namun bagaimanakah pemahaman dan implementasi ajaran Tri Hita Karana bagi para Penyuluh Agama Hindu? Permasalahan ini muncul untuk mengetahui pemahaman dan implementasi dari Penyuluh Agama Hindu mengenai konsep Tri Hita Karana. Hal ini dikaji menggunakan Metode Kualitatif, Pengambilan data wawancara dengan informen, berlokasi di Kementerian agama Kabupaten Tabanan.
\end{abstract}


Berdasarkan penelitian ditemukan metode yang digunakan oleh penyuluh dalam menjelaskan konsep Tri Hita Karana masih kurang. Penyuluh perlu meningkatkan kompetensinya dalam bidang penyuluhan terutama metode dan strategi penyuluhan. Maka berdasarkan KMA No. 516 Balai Diklat Keagamaan memiliki tugas untuk memberikan diklat kepada penyuluh.

Kata Kunci: Penyuluh Agama, Tri Hita Karana.

\section{PENDAHULUAN}

Agama mempunyai kedudukan dan peranan yang sangat penting dan strategis, utamanya sebagai landasan spiritual, moral dan etika dalam hidup dan kehidupan umat manusia. Berbangsa dan bernegara tidak lepas dari pada kontrol masyarakat dalam memberikan penyuluhan.Para penyuluh agama Hindu harus dibekali dengan strategi penyuluhan agama merupakan bagian dari fungsi Diklat. Sehingga program diklat mewujudkan SDM yang handal. Perubahan merupakan yang harus menjadi bagian dari konteks masyarakat pada umumnya. Perubahan itu sendiri mensyaratkan salah satunya adalah adanya ikon perubahan yang menjadi inspirator dan sekaligus motor penggerak menuju situasi yang lebih diinginkan pada setiap hal. Untuk menciptakan salah satu penggerak perubahan pada masyarakat adalah para tenaga penyuluh agama. Para penyuluh agama mempunyai peran penting dalam masyarakat menuju kehidupan yang lebih religius, yang menempatkan nilai-nilai agama sebagai basis perubahan menuju kehidupan yang harmonis, aman tentram dan sejahtera lahir batin. Namun dalam melakukan penyuluhan, penyuluh memiliki tantangan yang besar.Tantangan yang dihadapi penyuluh agama sebagai inspirator dan motor penggerak perubahan ini diantaranya ialah dari aspek sosio ekonomi masyarakat yang beragam, keragaman budaya, keragaman jenjang pendidikan dan pengetahuan masyarakat binanya yang berarti pula beragam tingkat pemahaman dan wawasan masyarakatnya.

Tantangan ini baru bersifat internal kemasyarakatan. Belum lagi jika ditambahkan dengan tantangan-tantangan eksternal kemasyarakatan yang muncul dari kepentingankepentingan golongan tertentu yang mengancam harmonisasi interaksi didalam pembinaan umat. Pembinaan umat khususnya pembinaan umat dalam Agama Hindu memanfaatkan tenaga Penyuluh Agama Hindu, terutana dalam meningkiatkan Sradha dan Bhakti melalui penjabaran konsep Tri Hita Karana sangat dibutuhkan peran penyuluh dalam menerapkan kepada masyarakat agar ketrerpanggilan untuk hidup yang harmonis anatara manusia denga Tuhan; manusia dengan sesama manusia, anatara manusia dengan lingkungan hidup. Secara individu manusia ingin hidup senang dan bahagia serta menghindarkan diri dari hal-hal yang menyusahkan dan menyengsarakan dirinya. Namun manusia tidak dapat hidup sendiri. Ia selalu membutuhkan bantuan orang lain. Dari sejak lahir hingga meninggal manusia membutuhkan bantuan orang lain. Karenanya manusia dikatakan mahluk sosial, yang secara naluriah memerlukan hubungan dan kerjasama dengan manusia lain dalam usaha memenuhi kebutuhan hidup lahir dan batin. Namun beberapa tahun belakangan ini berbagai konflik muncul mengenai permasalahan sengketa adat. Sengketa adat yang ada baik antara para pihak maupun mengenai wilayah. Pergesekan permasalahan wilayah yang saat ini sensitif yang sering terjadi dalam pemekaran suatu wilayah. Pemekaran suatu wilayah tidak lah mudah dalam suatu wilayah. Seringkali dalam pemekaran suatu wilayah sengketa lahan 
(Tanah) menjadi sesuatu yang sensitif. Di mana suatu tanah memiliki ekonomis yang tinggi bagi setiap pihak. Apalagi jika sengketa itu melibatkan antar desa pakraman. Misalnya sengketa yang terjadi antara Desa Pakraman Cekik dengan Desa Pakraman Gablogan Kabupaten Tabanan dimana sengketa ini dipicu oleh berbagai faktor sehingga menjadi kompleks. Permasalahan-permasalahan yang kompleks ini mengakibatkan kekerasan yang timbul dalam masyarakat. Kekerasan yang melibatkan masyarakat Bali kini jumlahnya cenderung meningkat. Sejumlah kasus adat yang mencuat ke permukaan mengindikasikan makin beringasnya orang Bali dalam menyikapi permasalahan. Perebutan lahan kuburan, pelaba pura, tapal batas, hingga pertikaian karena warisan, tak hanya menimbulkan sengketa perdata, tetapi telah berada di jalur pidana. Dalam hal perebutan warisan sesama krama Bali ada yang tega melakukan pembunuhan. Masyarakat yang memiliki pemahaman yang memadai mengenai Tri Hita Karana akan meminimalisir konflik-konflik yang terjadi di dalam masyarakat. Penyuluh dalam hal ini memiliki andil besar dalam memberikan pengetahuan kepada masyarakat. Keputusan Menteri Agama (KMA) Nomor 516 tahun 2003 tentang Petunjuk Teknis Pelaksanaan Jabatan Penyuluh Fungsional, yaitu dengan melakukan dan mengembangkan kegiatan bimbingan atau penyuluhan agama dan pembangunan melalui bahasa agama kepada masyarakat". Berdasarkan Keputusan Menteri Agama (KMA) Nomor 79 tahun 1985 bahwa: "Penyuluh Agama memiliki peranan sebagai pembimbing masyarakat, sebagai panutan dan sebagai penyambung tugas pemerintah".

Berdasarkan KMA Nomor 516 ini maka jelas peran dari penyuluh dalam membimbing masyarakat yang sebagian besar pada saat ini memiliki emosi yang bergejolak akibat sengketa-sengketa tersebut. Maka sangatlah penting dalam membina penyuluh dalam memahami permasalahan yang ada dengan memberikan pendidikan dan pemahaman mengenai konsep Tri Hita Karana yang sudah mulai terkikis eksistensinya dan penerapannya dalam masyarakat. Pendidikan yang cukup dan emosi yang setabil pada masyarakatlah yang menyebabkan bangsa dapat menjadi bangsa yang kuat dan beradab dalam menghadapi perkembangan era modernisasi (globalisasi) yang semakin mengikis rasa kebersamaan dan persaudaraan.

\section{Rumusan Masalah}

Bagaimanakah pemahaman ajaran Tri Hita Karana bagi para Penyuluh Agama Hindu dan peranan para Penyuluh Agama Hindu di dalam mengimplementasikan ajaran Tri Hita Karana bagi Masyarakat Kabupaten Tabanan?

\section{Tujuan Penelitian}

Penelitian ini bertujuan untuk mengetahui pemahaman dan mengimplementasikan para Penyuluh Agama Hindu terhadap ajaran Tri Hita Karana bagi masyarakat Kabupaten Tabanan

\section{KAJIAN TEORI}

Penelitian ini terkait dengan antropologi pendidikan yang mempelajari peristiwa kultural/budaya Bali dengan latar belakang ideologi Tri Hita Karana menggunakan landasan filsafat phenomenologi (Noeng Muhadjir, 2000). Penelitan ini menuntut pendekatan holistik, mengamati subjek penelitian dalam konteks, dalam keseluruhan, tidak diparsialkan, tidak dieliminasi dari integritasnya. Peneliti tertarik dengan proses dan makna sehingga secara fisik pergi ke lapangan mengobservasi dan melakukan 
interview terhadap orang-orang dalam seting yang alamiah (Creswell, 1994). Dalam pandangan (Spradley 1979) penelitian etnografi adalah study from people. Penelitian ini menuntut menyatunya subjek penelitian dengan obyek penelitian serta subjek pendukungnya. Sehingga keterlibatan langsung dikancah dan menghayati berprosesnya subjek penelitian, subjek pendukung penelitian dan objek penelitian menjadi syarat utama. Penelitian etnografi tentang konsepsi masyarakat di Tabanan terhadap Penyuluh Hindu yang memiliki kedudukan sebagai pelaksana teknis fungsional bimbingan keagamaan hindu atau penyuluh pembangunan melalui bahasa agama Hindu kepada masyarakat (pedoman pelaksanaan tugas penyuluh agama Hindu, 2012).

Penelitian mengenai penyuluh ini memiliki kompetensi yang mengarah ke empat dimensi yaitu induktif, generatif, konstruktif, dan subjektif (Noeng Muhadjir, 2000). Konsepsi induktif berharap menemukan teori dari data, mengumpulkan dan menganalisis data untuk mengembangkan teori. Generatif mengarah ke penemuan konstruksi dan proposisi dengan menggunakan data sebagai evidensi. Konstruktif mengarah kepada penemuan konstruksi atau kategori lewat analisis dan proses mengabstraksi. Subjektif artinya rekonstruksi penafsiran dan pemaknaan hasil penelitian didasarkan kepada konseptualisasi masyarakat Tabanan dalam memahami, mengintepretasikan, menjelaskan dan menggambarkan pola pembudayaan kompetensi didalam kehidupan bermasyarakat dan beragama dengan konsep Tri Hita Karana. Studi etnografi menurut Goetz dan La Compte (1984) menekankan pembentukan teori berdasarkan data empirik,teori dikonstruksi di lapangan (grounded theory).

Kamus Besar Bahasa Indonesia dinyatakan teori adalah 1) pendapat yang dikemukakan sebagai suatu keterangan mengenai sesuatu peristiwa (kejadian dsb.); mis,-tentang terjadinya bumi; - Darwin tentang evolusi; 2) Azas-azas dan hokum-hukum umum yang menjadi dasar sesuatu kesenian atau ilmu pengetahuan, mis, - melukis, - karangmengarang, - hitungan, - pelayaran; 3) Pendapat cara-cara dan aturan-aturan untuk melakukan sesuatu (Poewadarminta, 1976).

Selanjutnya Kerlinger menyatakan teori adalah seperangkat konstuk (konsep), definisi, dan proporsi yang berfungsi untuk melihat fenomena secara sistematik, melalui spesifikasi hubungan antara variabal, sehingga dapat berguna untuk menjelaskan dan meramalkan fenomena (Sugiyono, 2007)

\section{Teori Relegi}

Teori relegi merupakan teori-teori terpenting tentang asal mula dan inti relegi.

Masalah asal mula dan inti dari suatu unsur universal seperti relegi atau Agama itu, tegasnya masalah mengapakah manusia percaya kepada suatu kekuatan yang dianggap lebih tinggi dari padanya, dan masalah mengapakah manusia melakukan berbagai hal dengan cara-cara yang beraneka warna untuk mencari hubungan dengan kekuatankekuatan tadi. Adapun mengenai soal itu dalam teori azas relegi ada berbagai pendirian dan teori yang berbeda-beda. Menurut Koentjaraningrat (1992) membedakan teori-teori itu menjadi enam kategori :

a. Teori bahwa kelakuan manusia yang bersifat relegi itu terjadi karena manusia mulai sadar akan adanya paham jiwa.

b. Teori bahwa kelakuan manusia yang bersifat relegi itu terjadi karena manusia mengakui adanya banyak gejala yang tidak dapat diterangkan dengan akalnya.

c. Teori bahwa kelakuan manusia yang bersifat relegi itu terjadi dengan maksud untuk menghadapi krisis-krisis yang ada dalam jangka waktu hidup manusia. 
d. Teori bahwa kelakuan manusia yang bersifat relegi terjadi karena kejadian-kejadian luar biasa dalam hidupnya dan alam sekelilingnya.

e. Teori bahwa kelakuan manusia yang bersifat relegi terjadi karena suatu getaran atau emosi yang ditimbulakn dalam jiwa manusia sebagi akibat dari pengaruh rasa kesatuan sebagai warga masyarakatnya.

f. Teori bahwa kelakuan manusia yang bersifat relegi terjadi karena manusia mendapat suatu firman dari Tuhan.

\section{Teori sombol}

Manusia yang berinteraksi dengan lingkungan hidupnya tidak lepas dari simbol, karena simbol mampu mengungkapkan sesuatu dalam pikirannya. Simbol dapat memberikan arahan bagi perhatian orang dalam pemilihan alat-alat tertentu atau penentuan cara tertentu yang dipakai untuk mencapai tujuannya. Selain itu simbol-simbol dapat membangkitkan emosi serta mendorong orang untuk bereaksi. Interkasionisme-simbolik menunujuk pada sifat yang khas dari interaksi antar manusia yang diantaranya oleh penggunaan simbol-simbol, serta interpretasi terhadap simbol-simbol. Simbol adalah sesuatu hal atau keadaan yang merupakan pengantar pemahaman terhadap obyek.Simbol berfungsi memimpin pemahaman si subyek kepada obyek (Triguna, 1996). Selanjutnya Moleong juga menyebutkan bagian lain yang penting dari teori interaksi simbolik ialah kontrak tentang diri. Diri tidak dilihat sebagai yang berada dalam individu seperti aku atau kebutuhan yang teratur, motivasi dan norma serta nilai dari dalam. Diri adalah definisi yang diciptakan orang (melalui interaksi dengan yang lainnya) di tempat ia berada. Dalam menkonstruk atau mendefinisikan aku, manusia mencoba melihat dirinya sebagai orang lain, dengan jalan menafsirkan tindakan dan isyarat yang diarahkan kepada mereka dan dengan jalan menempatkan dirinya dalam peranan orang lain (Moleong, 2009)

\section{Teori Komunikasi Kelompok}

Menurut Burhan Bungin komunikasi dalam kelompok merupakan bagian dari kegiatan keseharian orang. Sejak lahir, orang sudah mulai bergabung dengan kelompok primer yang paling dekat, yaitu keluarga. Kemudian seiring dengan perkembangan usia dan kemampuan intelektual kita masukdan terlibat dalam kelompok-kelompok sekunder seperti sekolah, lembaga agama, tempat pekerjaan dan kelompok sekunder lainnya yang sesuai dengan minat dan keterikatan kita, ringkasnya kelompok merupakan bagian yang tidak terpisahkan dengan kehidupan kita, karena melalui kelompok, memungkinkan kita dapat berbagi informasi, pengalaman, dan pengetahuan kita dengan anggota kelompok lainnya (Bungin,2009;261).

\section{KAJIAN PUSTAKA}

Ideologi Tri Hita Karana adalah sistesa pemikiran yang dicetuskan oleh Dr. I Wayan Mertha Suteja pada tanggal 11 Nopember 1966 dalam Konferensi Daerah I Badan Perjuangan Umat Hindu Bali di Perguruan Dwijendra Denpasar Bali. Kemudian ideologi Tri Hita Karana dipopulerkan oleh I Gusti Ketut Kaler dan I Made Djapa BA (Titib, 2003). Pendalaman konsep Tri Hita Karana juga diungkap oleh Agastia dalam Majalah Warta Hindu Dharma No. 491 Tahun 2007.

Menurut I Gusti Ketut Kaler dikutip oleh Agastia (2007) Tri Hita Karana adalah tiga buah unsur yang merupakan sumber sebab timbulnya kebaikan. Dalam Widhi Tatwa (filsafat ke-Tuhan-an) tersurat bahwa zat dari Tuhan (Hyang Widhi) meresap (wyapi) memasuki segenap alam semesta/makrokosmos (bhuwana agung), termasuk meresap juga kedalam 
mikrokosmos (bhuwana alit) yaitu diri manusia. Kedua bhuwana ini yaitu alam semesta (bhuwana agung) dan diri manusia (bhuwana alit) masing-masing memiliki badan wadag (sarira). Manunggalnya zat resapan Tuhan dengan badan wadag kedua bhuwana itu menimbulkan unsur baru yang disebut dengan prana (daya atau kekuatan) berupa kemampuan bergerak (bayu), kemampuan berbicara (sabda), kemampuan berpikir (idep).

Ketiga unsur ini yaitu: 1) Zat Tuhan; 2) prana (daya/kekuatan); dan 3) sarira (badan wadag) disebut sebagai Tri Hita Karana. Secara leksikal Tri Hita Karana berarti tiga penyebab kesejahteraan dan kebahagiaan. Tri artinya tiga; Hita artinya hidup, sejahtera, bahagia, lestari, makmur; Karana artinya penyebab. Jadi Tri Hita Karana mengandung pengertian tiga penyebab kesejahteraan dan kebahagiaan.

Ideologi Tri Hita Karana mengajarkan bahwa kesejahteraan atau kebahagiaan bersumber atau disebabkan oleh adanya tiga unsur utama yaitu: 1) jiwa/atma; 2) daya/kekuatan/prana; dan 3) fisik/badan wadag/angga. Kebahagiaan atau kesejahteraan (hita) dapat terwujud jika ada tiga penyebab (tri karana) yaitu jiwa, tenaga, dan fisik. Hilangnya salah satu dari ketiga penyebab kebahagiaan ini akan menghilangkan kebahagiaan itu sendiri.

Pengejawantahan Tri Hita Karana dalam bhuwana alit atau diri manusia adalah: 1) atman atau zat Hyang Widhi Wasa yang meresap dalam diri manusia merupakan jiwa yang menyebabkan manusia hidup; 2) prana atau tenaga adalah kekuatan dalam bentuk sabda-bayu-idep sebagai daya yang timbul karena menyatunya Atma dengan sarira atau badan wadag; 3) sarira atau badan wadag manusia terbentuk dari lima unsur yang disebut dengan panca mahabhuta. Pengejawantahan Tri Hita Karana dalam makrokosmos (bhuwana agung) atau alam raya adalah: 1) paramatma atau zat Hyang Widhi Wasa yang meresap pada alam semesta selaku kesatuan, dimana paramatma merupakan jiwa alam raya; 2) prana atau tenaga adalah kekuatan yang memutar planit, laut, angin, listrik, magnit, nuklir dan sebagainya adalah tenaganya; 3) keseluruhan alam selaku totalitas, merupakan badan wadag. Jadi Atma/Paramatma, Prana, dan Sarira/Panca Mahabhuta yang manunggal dalam bhuwana alit dan bhuwana agung merupakan unsur mutlak untuk mendapatkan kebahagiaan, sehingga dinamakan Tri Hita Karana.

Ideologi Tri Hita Karana menegaskan bahwa siapapun yang hidup sebagai manusia memiliki modal dasar kebahagiaan dan kesejahterteraan yang sama. Dalam kaitannya dengan pengembangan kompetensi kejuruan untuk mewujudkan kesejahteraan dan kebahagiaanan seseorang harus menghayati modal Tri Hita Karana dan mengamalkan Tri Hita Karana. Manusia pendidikan kejuruan memerlukan fisik atau badan sebagai angga yang sehat dan bugar. Kompetensi kejuruan dikembangkan dengan melatih alat gerak (tangan, kaki, mulut), alat indria (telinga, mata, lidah, hidung, kulit), kemampuan berbicara (sabda), kemampuan bergerak (bayu), dan kemampuan berpikir (idep). Keterampilan menyoder bisa tumbuh dengan baik jika unsur prana yaitu sabda, bayu, dan idep berkembang dengan baik. Agar menjadi manusia terampil dan bernilai seseorang perlu juga mengembangkan kemampuan dan kapasitas berkomunikasi (sabda), kemampuan dan kapasitas tenaga (bayu), dan kemampuan dan kapasitas berpikir (idep). Contoh lain adalah antara janin sebagai "manik" dengan rahim ibu sebagai "cecupu" yang harmonis tiada tara sebagai pertalian antara isi dengan wadahnya. Sehingga kebudayaan Bali menyatakan kedua materi ini sebagai bhuwana alit (manik) dan bhuwana agung (cecupu). Lebih lanjut Agastia (2007) menyatakan 
manusia sebagai mahluk berpikir dan berbudaya mengembangkan wadah bagi dirinya. Manusia membuat rumah, banjar, desa adat, bahkan Negara selaku wadah bersama baginya. Harapannya adalah agar wadah buatannya ini memberikan rasa bahagia serta mempunyai pertalian serasi dengan manusia selaku isinya. Maka demi kebahagiaan ini dikonsepsikanlah rumah dan desa sebagai wadah buatan. Kebahagiaan (hita) bersumber dari keharmonisan hubungan antara: 1) manusia dengan Tuhan; 2) manusia dengan sesamanya; 3) manusia dengan alam lingkungannya.

Harmonis berarti melakukan hal-hal yang mengandung kebaikan, kesucian yang dimulai dari pikiran, terucap dalam perkataan dan terlihat dalam tindakan/perbuatan (Raka Santeri, Kompas: 5 Desember 2017). Keharmonisan pikiran, perkataan, dan perbuatan menurut Gede Prama adalah keindahan hidup (Bali Pos, 3 Oktober 2018). Tri Hita Karana dalam unsur bhuwana agung maupun bhuwana alit yang terdiri atas jiwa, prana, dan sarira yang dalam wadah buatan dieralisasikan dalam tiga "Pa" yaitu: Parhyangan, Pawongan, dan Palemahan. Ketiga unsur tersebut adalah sesuatu yang sistemik, memiliki keterkaitan satu sama lain dalam sebuah kemanunggalan untuk mencapai kebahagiaan. Jika demikian Kementerian Agama Kabupaten Tabanan adalah wadah sedangkan isinya adalah pegawainya (penyuluh Agama) yang termasuk dalam bagian dari Tri Hita Karana.

Antara bhuwana agung dan bhuwana alit memiliki unsur yang sama yaitu Tri Hita Karana. Kemudian konsepsi tiga sumber kehidupan atau Tri Hita Karana melandasi terwujudnya susunan makrokosmos dan mikrokosmos. Tri Hita Karana dalam susunan unsur kosmos digambarkan dalam gambar 1.

TRI HITA KARANA DALAM SUSUNAN KOSMOS

\begin{tabular}{|l|l|l|l|}
\hline \multicolumn{3}{|c|}{ TRI HITA KARANA DALAM SUSUNAN } \\
\hline $\begin{array}{l}\text { Susunan } \\
\text { /unsur }\end{array}$ & $\begin{array}{l}\text { Jiwa/Atma } \\
\text { n }\end{array}$ & $\begin{array}{l}\text { Prana/te } \\
\text { naga }\end{array}$ & $\begin{array}{l}\text { Sarira/ } \\
\text { fisik }\end{array}$ \\
\hline $\begin{array}{l}\text { Alam } \\
\text { smesta } \\
\text { (Makrok } \\
\text { osmos) }\end{array}$ & $\begin{array}{l}\text { Tuhan } \\
\text { Yang } \\
\text { Maha Esa } \\
\text { (Paramat } \\
\text { man) }\end{array}$ & $\begin{array}{l}\text { Matahar } \\
\text { i dan } \\
\text { Bulan }\end{array}$ & $\begin{array}{l}\text { Bumi } \\
\text { dengan } \\
\text { segala } \\
\text { isinya }\end{array}$ \\
\hline $\begin{array}{l}\text { Manusia } \\
\text { (Mikrok } \\
\text { osmos) }\end{array}$ & $\begin{array}{l}\text { Jiwa/Atma } \\
\text { n }\end{array}$ & $\begin{array}{l}\text { Sabda, } \\
\text { Bayu, } \\
\text { Idep }\end{array}$ & Badan \\
\hline $\begin{array}{l}\text { Rumah } \\
\text { Irahyanga } \\
\text { Sanggah } \\
\text { Pemerajan } \\
\text { Pawong } \\
\text { (Warga } \\
\text { di } \\
\text { rumah) }\end{array}$ & $\begin{array}{l}\text { Palemah } \\
\text { an } \\
\text { (Pekaran } \\
\text { gan } \\
\text { Rumah) }\end{array}$ \\
\hline Banjar & $\begin{array}{l}\text { Prahyanga } \\
\text { n, Pura, } \\
\text { Bale } \\
\text { Banjar }\end{array}$ & $\begin{array}{l}\text { Pawong } \\
\text { an } \\
\text { (Warga } \\
\text { di } \\
\text { banjar) }\end{array}$ & $\begin{array}{l}\text { Pawonga } \\
\text { narga } \\
\text { di banjar) }\end{array}$ \\
\hline $\begin{array}{l}\text { Desa } \\
\text { (Kelura }\end{array}$ & $\begin{array}{l}\text { Parahyang } \\
\text { an, Pura }\end{array}$ & $\begin{array}{l}\text { Pawong } \\
\text { an }\end{array}$ & $\begin{array}{l}\text { Palemah } \\
\text { an }\end{array}$ \\
\hline
\end{tabular}




\begin{tabular}{|l|l|l|l|}
\hline han) & $\begin{array}{l}\text { Bale } \\
\text { Agung, } \\
\text { Puseh, } \\
\text { Dalem }\end{array}$ & $\begin{array}{l}\text { (Warga } \\
\text { desa } \\
\text { pakrama } \\
\text { n) }\end{array}$ & $\begin{array}{l}\text { (Wilayah } \\
\text { Desa) }\end{array}$ \\
\hline $\begin{array}{l}\text { Kabupat } \\
\text { en/kota }\end{array}$ & $\begin{array}{l}\text { Parahyang } \\
\text { an,Pura } \\
\text { Jagatnatha }\end{array}$ & $\begin{array}{l}\text { Pawong } \\
\text { an } \\
\text { (Warga } \\
\text { Kabupat } \\
\text { en) }\end{array}$ & $\begin{array}{l}\text { Palemah } \\
\text { an } \\
\text { (Wilayah } \\
\text { Kota) }\end{array}$ \\
\hline Kantor & $\begin{array}{l}\text { Parahyang } \\
\text { an, Pura, } \\
\text { Kantor }\end{array}$ & $\begin{array}{l}\text { Pawong } \\
\text { an } \\
\text { (pegawa } \\
\text { i) }\end{array}$ & $\begin{array}{l}\text { Palemah } \\
\text { an } \\
\text { (Pakaran } \\
\text { gan } \\
\text { Kantor) }\end{array}$ \\
\hline
\end{tabular}

\section{KERANGKA BERPIKIR}

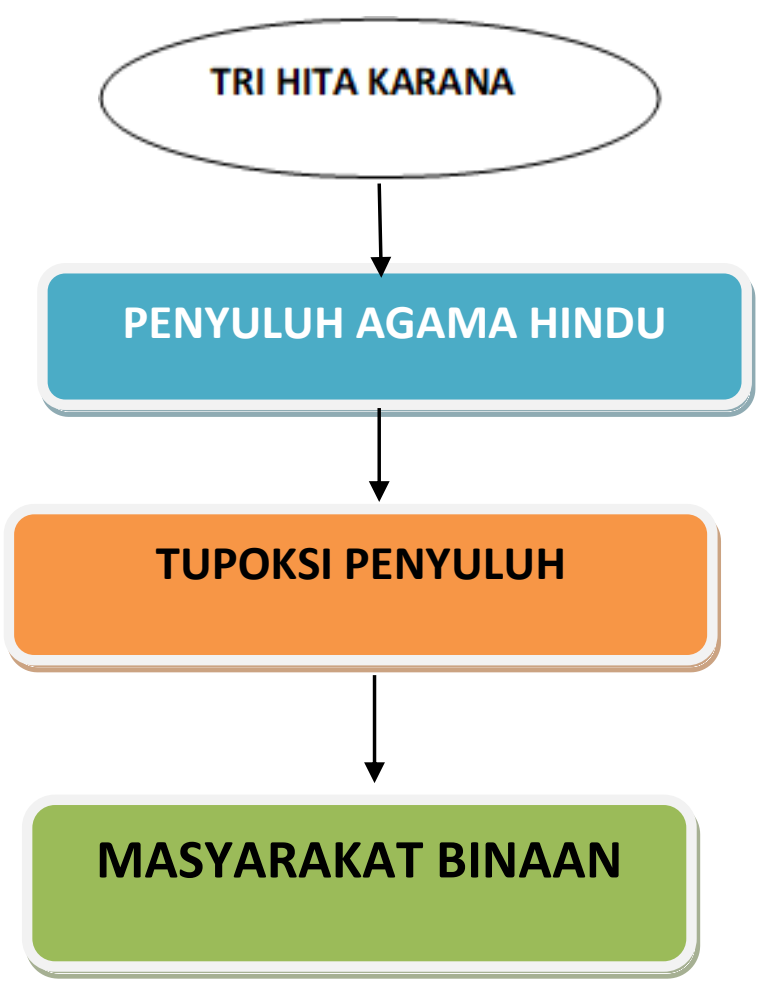

\section{METODE PENELITIAN}

Metode penelitian yang digunakan dalam penelitian ini adalah metode penelitian kualitatif. Penelitian ini dilaksanakan di Kementerian Agama kabupaten Tabanan. Pemilihan lokasi di kabupaten Tabanan secara purposif dipandang mewakili permasalahan-permasalahan yang ada di Tabanan pada saat ini. Terdapatnya berbagai konflik yang sensitif dan banyak konflik anatara anggota masyarakat yang lainnya.

Subjek dan objek penelitian adalah sumber-sumber data-data penelitian. Menurut Mason (2006) sumber data penelitian kualitatif yaitu orang-orang baik individu atau kelompok, 
organisasi, institusi, teks terpublikasi atau tidak terpublikasi, seting lingkungan, seting budaya, objek materi, artefak, produk media, peristiwa atau kejadian. Dalam terminologi penelitian kualitatif Spradley (1979) lebih menyarankan penggunaan istilah informan penelitian dari pada subjek penelitian untuk sumber-sumber data dari orang. Karena informan penelitian ditempatkan dalam posisi aktif mengetahui budaya yang akan diteliti, memiliki dan mampu mendefinisikan konsep, sebagai kunci utama data penelitian (Tanggaard, 2009; Ajodhia \& Berman, 2009; Cho \& Trent, 2009). Subjek penelitian ini melibatkan informan berasal penyuluh agama Hindu.

Interview kualitatif dilakukan terhadap sumber-sumber data dari orang-orang yang dipilih sebagai informan. Istilah interview kualitatif menurut Tanggaard, 2009; Ajodhia \& Berman, 2009; Cho \& Trent, 2009) dimaksudkan merujuk kepada bentuk-bentuk interview yang mendalam (in-depth), semi terstruktur atau strukturnya agak longgar. Interview kualitatif melibatkan interaksi satu lawan satu (one-to-one), interview kelompok besar atau focus groups melalui tatap muka (face-to-face), telepon, atau internet (Hall, Lashua, Coffey, 2009; Bryman \& Cassell, 2006; Carlin, 2009; Briggs, 2007).

Interview kualitatif sangat bermanfaat untuk menggali data kualitatif jika informan tidak dapat di observasi secara langsung (Creswell, 1994). Kebanyakan penelitian kualitatif dilakukan dari perspektif bahwa pengetahuan itu situasional dan kontekstual. Dengan demikian pekerjaan interview harus memberi jaminan bahwa kontek yang relevan dijadikan fokus interview dalam memproduksi pengetahuan yang situasional dan kontekstual. Data dikonstruksi melalui interaksi dialogis diantara orang yang diinterview dengan interviewer selama proses interview.

Berdasarkan analisis data penelitian di daerah Tabanan, peneliti menemukan beberapa penemuan penelitian yakni : 1) Kesempatan pendidikan dan pelatihan bagi para penyuluh yang dilakukan oleh Balai Diklat Keagamaan Denpasar masih terbatas; 2) Pemahaman yang dimiliki para Penyuluh Agama Hindu terkait dengan ajaran Tri Hita Karana masih terbatas untuk pengajawantahannya dalam kehidupan sehari-hari; 3) Proses pelaksanaan penyuluhan, pendekatan dan kemampuan metodis para penyuluh agama hindu masih kurang memadai sebagai bentuk proses pendidikan (non-formal) yang dapat memberdayakan kesadaran dan pengamalan khususnya dan kehidupan secara lebih luas pada umumnya.

\section{PEMBAHASAN}

\section{Ajaran Tri Hita Karana}

Istilah Tri Hita Karana pertama kali muncul pada tanggal 11 Nopember 1966, pada waktu diselenggarakan Konferensi Daerah 1 Badan Perjuangan Umat Hindu Bali bertempat di Perguruan Dwijendra Denpasar. Konferensi tersebut diadakan berlandaskan kesadaran umat Hindu akan dharmanya untuk berperan serta dalam pembangunan bangsa yang menuju masyarakat sejahtera, adil dan makmur berdasarkan Pancasila. Kemudian istilah Tri Hita Karana ini berkembang, meluas, dan memasyarakat. Tri Hita Karana berasal dari bahasa sansekerta dari kata Tri yang berarti tiga, Hita berarti sejahtera dan Karana berarti penyebab.

Pengertian Tri Hita Karana adalah tiga hal pokok yang menyebabkan kesejahteraan dan kemakmuran hidup manusia. Secara leksikal Tri Hita Karana berarti tiga penyebab kesejahteraan. (Tri berarti tiga, Hita berarti sejahtera, Karana artinya penyebab). Pada hakikatnya Tri Hita Karana mengandung pengertian tiga penyebab kesejahteraan itu bersumber pada keharmonisan hubungan antara: Manusia dengan Tuhannya. Manusia 
dengan alam lingkungannya. Manusia dengan sesamanya. Konsep ini muncul berkaitan erat dengan keberadaan hidup bermasyarakat di Bali. Berawal dari pola hidup ini muncul dan berkaitan dengan terwujudnya suatu desa adat di Bali. Dengan demikian suatu ciri khas desa adat di Bali minimal mempunyai tiga unsur pokok,yakni :wilayah, masyarakat dan tempat suci untu memuja Tuhan/Sang Hyang Widhi. Perpaduan tiga unsur itu secara harmonis sebagai landasan untuk terciptanya rasa hidup yang nyaman, tenteram, dan damai secara lahiriah maupun bathiniah. Menurut Wiana (2004) falsafah hidup berdasarkan Tri Hita Karana ini memang sudah diajarkan dalam kitab suci Bhagawad Gita III.10, meskipun dalam kitab tersebut tidak bernama Tri Hita Karana, dalam kitab tersebut dinyatakan Tuhan (Prajapati) telah beryadnya menciptakan alam semesta dengan segala isinya. Karena iti manusia (Praja) hendaknya beryadnya kepada Tuhan (Prajapati), kepada sesama manusia (Praja) dan kepada lingkungannya (Kamadhuk).

Tri Hita Karana merupakan konsep bermasyarakat yang perlu mendapatkan pendalaman yang mendalam, pada umumnya diklat yang diberikan oleh penyuluh merupakan diklat yang berkaitan dengan administratif dan tekhnik saja (Hasil wawancara 11 Desember 2018, Dengan Agus Putrayasa, Penyuluh Agama Hindu). Selain itu masyarakat tidak terlalu memahami mengenai konsep yang seutuhnya dari Tri Hita Karana. Karena Sebagian Besar Dari Penyuluh Kurang menjelaskan konsep dari Tri Hita Karana. Penjelasan yang diberikan pada dasarnya hanya mengenai pengertian yang mendasar namun kurang mendalam dalam pengertian konsep Tri Hita Karana (hasil wawancaa 11 Desember 2018, Ketut Budi, Penyuluh Agama Hindu).

\section{Penyuluh Agama Hindu}

Penyuluh agama memiliki kedudukan sebagai pelaksana tekhis fungsional bimbingan keagamaan Hindu atau penyuluh pembangunan melalui bahasa agama Hindu kepada masyarakat (pedoman pelaksanaan tugas penyuluh agama Hindu, 2012). Untuk menemukan sendiri jawaban tersebut sebab hanya ia sendiri yang tahu persis pedoman pelaksanaan tugas penyuluh agama Hindu, 2012). menyebutkan bahwa untuk meningkatkan mutu profesionalisme dan pembinaan karir Pegawai Negeri Sipil perlu ditetapkan jabatan fungsional. Untuk menindaklanjuti peraturan tersebut maka dikeluarkan Keputusan Presiden Nomor 87 Tahun 1999 tentang Rumpun Jabatan Fungsional Pegawai Negeri Sipil yang salah satunya menetapkan Penyuluh Agama adalah jabatan fungsional Pegawai Negeri yang termasuk ke dalam rumpun jabatan keagamaan.

Kedua peraturan ini menjadi landasan yuridis keberadaan Penyuluh Agama dengan tugas dan fungsi utamanya memberikan pelayanan agama dan keagamaan, sekaligus sebagai wadah pembinaan karir Pegawai Negeri Sipil.Keputusan Menteri Negara Koordinator Bidang Pengawasan Pembangunan dan Pendayagunaan Aparatur Negara Nomor: 54/Kep/MK.WASPAN/9/1999, tanggal 30 September 1999 tentang Jabatan Fungsional Penyuluh Agama dan Angka Kreditnya. Kemudian, berdasarkan jenisnya Penyuluh Agama dibedakan menjadi dua, yaitu Penyuluh Agama Bidang dan Penyuluh Spesialisasi. Dalam hal ini Penyuluh Agama Hindu tergolong dalam jenis Penyuluh Agama Bidang, yakni Bidang Agama Hindu. Penyuluhan kata dasarnya adalah suluh yang berarti penerang. Dalam pengertian ini maka penyuluhan berarti kegiatan memberikan penerangan. Kepada siapa? Yaitu kepada sasaran (masyarakat) binaannya, baik itu individu maupun kelompok, terbatas atau bahkan masyarakat luas dengan segala karakteristiknya yang khas. Penyuluhan dapat juga diartikan sebagai kegiatan 
pemberian bimbingan atau pimpinan kepada objek penyuluhan agar objek tersebut mampu menemukan solusi-solusi yang relevan dengan permasalahan yang dihadapinya. Dalam pengertian ini maka penyuluh tidak berkompeten untuk memberikan jawaban langsung mengenai persoalan yang dihadapi oleh binaannya. Melainkan ia dibimbing persoalan-persoalannya. Berbicara tentang tugas fasilitatif pada sebuah instansi atau kantor, perlu diungkap terlebih dahulu tentang makna tugas. Secara esensial pada sebuah instansi, tugas terdiri dari tiga karakteristik, yakni: tugas pokok, tugas penunjang, dan tugas tambahan (Syamsuddin HA, 2005: 27). Tugas pokok adalah tugas utama yang merupakan jabatan langsung fungsi dan tugas organisasi, tugas penunjang adalah tugas fungsinya menunjang suksesnya tugas pokok, sedangkan tugas tambahan adalah tugas yang pada dasarnya tidak menjadi tugas jabatan yang bersangkutan. Dalam KMA No. 555 Tahun 2003 tentang Pedoman Koordinasi di Lingkungan Kementrian Agama memiliki tugas pokok disebut juga dengan tugas substantif dan tugas penunjang disebut juga dengan tugas fasilitatif. Tugas substantif adalah tugas yang diamanahkan sebagai tugas pokok atau inti dari sebuah instansi. Hal ini dapat dilihat dari makna substansi, yaitu watak yang sebenarnya dari sesuatu, isi atau pokok (KBBI, 2001: 1095). Tugas fasilitatif adalah tugas yang dikerjakan untuk menunjang tugas substantif. Hal ini dimaknai bahwa kata fasilitatif diartikan sebagai sarana untuk melancarkan pelaksanaan fungsi (KBBI, 2001: 314).

Berangkat dari makna di atas, maka Balai Diklat Keagamaan sebagai bagian dari institusi Departemen Agama juga memiliki tugas substantif dan fasilitatif. Sesuai dengan KMA No. 345 Tahun 2004 tentang Organisasi dan Tata Kerja Balai Diklat Keagamaan pada pasal 2 dijelaskan bahwa Balai Diklat Keagamaan mempunyai tugas melaksanakan pendidikan dan pelatihan tenaga administrai dan tenaga teknis keagamaan sesuai dengan wilayah kerja masing-masing. Sedangkan susunan organisasi Balai Diklat Keagamaan dapat ditemukan dalam pasal 4 yakni terdiri dari: Subbagian Tata Usaha, Seksi Diklat Tenaga Administrasi, Seksi Diklat Tenaga Teknis Keagamaan dan Kelompok Jabatan Fungsional.

Sebagai bagian dari tugas fasilitatif, dalam KMA No. 345 dapat ditemukan pada pasal 5 yakni tentang tugas Subbagian Tata Usaha yaitu melaksanakan pelayanan teknis dan administrasi bagi satuan kerja di lingkungan Balai Diklat Keagamaan. Pasal ini mempunyai makna bahwa Subbagian Tata Usaha harus mampu melakukan pelayanan teknis dan administrasi untuk kelancaran tugas-tugas pada Diklat Tenaga Administrasi dan Diklat Tenaga Teknis Keagamaan. Dalam melaksanan tugas tersebut, Subbagian Tata Usaha menyelenggarakan fungsinya dapat ditemukan dalam pasal 8 yakni: 1) penyiapan bahan perumusan visi, misi, serta kebijakan Balai Diklat Keagamaan; 2) penyiapan program dan anggaran serta pembinaan, pengelolaan dan koordinasi di bidang keuangan dan IKN, organisasi dan ketatalaksanaan, kepegawaian, hukum dan hubungan masyarakat, informasi kediklatan, administrasi perkantoran dan kerumahtanggaan; dan 3) melaksanakan pelaksanaan evaluasi dam pelaporan teknis dan administrasi balai serta penyelesaian tindaklanjut hasil pengawasan.

\section{Peranan penyuluh agama hindu di dalam mengimplementasikan ajaran Tri Hita Karana bagi masyarakat Kab.Tabanan.}

Budaya atau kebudayaan berasal dari bahasa Sansekerta yaitu buddhayah, yang merupakan bentuk jamak dari buddhi (budi atau akal) diartikan sebagai hal-hal yang berkaitan dengan budi dan akal manusia. Dalam bahasa Inggris, kebudayaan disebut culture, yang berasal dari kata Latin Colere, yaitu mengolah atau mengerjakan. Bisa 
diartikan juga sebagai mengolah tanah atau bertani. Kata culture juga kadang diterjemahkan sebagai "kultur" dalam bahasa Indonesia. Kebudayaan didefinisikan sebagai keseluruhan pengetahuan manusia sebagai makhluk sosial yang digunakannya untuk memahami dan menginterprestasikan lingkungan dan pengalamanya, serta menjadi landasan bagi tingkah-lakunya.

Kebudayaan merupakan serangkaian aturan-aturan, petunjuk-petunjuk, rencanarencana, dan strategi-strategi yang terdiri atas serangkaian model-model kognitif yang dipunyai oleh manusia, dan digunakannya secara selektif dalam menghadapi lingkungannya sebagaimana terwujud dalam tingkahlaku dan tindakan-tindakannya. Selain itu kebudayaan dapat didefinisikan sebagai suatu keseluruhan pengetahuan manusia sebagai makhluk sosial yang digunakannya untuk memahami dan menginterpretasi lingkungan dan pengalamannya, serta menjadi pedoman bagi tingkah lakunya. Suatu kebudayaan merupakan milik bersama anggota suatu masyarakat atau suatu golongan sosial, yang penyebarannya kepada anggota-anggotanya dan pewarisannya kepada generasi berikutnya dilakukan melalui proses belajar dan dengan menggunakan simbol-simbol yang terwujud dalam bentuk yang terucapkan maupun yang tidak (termasuk juga berbagai peralatan yang dibuat oleh manusia). Dengan demikian, setiap anggota masyarakat mempunyai suatu pengetahuan mengenai kebudayaannya tersebut yang dapat tidak sama dengan anggota-anggota lainnya, disebabkan oleh pengalaman dan proses belajar yang berbeda dan karena lingkunganlingkungan yang mereka hadapi tidak selamanya sama. Melelui implementasi ajaran Tri Hita Karana, masyarakat sadar akan pentingnya keharmonisa hidup antara manusia dengan Tuhan sebagai sang pencipta, sesama manusia hidup rukun dan damai, antara manusia dengan lingkungan hidup. Bagi anggota masyarakat sangat bermanfaat hidup aman dan nyaman sesama warga masyarakat, dapat hidup: "segilik seguluk selunglung sebayan taka paras paros sarpanaya".

\section{PENUTUP}

\section{Simpulan}

Dari penjelasan dan penjabaran di atas maka dapat disimpulkan sebagai berikut:

a. Penyuluh Agama adalah jabatan fungsional Pegawai Negeri yang termasuk ke dalam rumpun jabatan keagamaan. Balai Diklat Keagamaan memiliki tugas melaksanakan pendidikan dan pelatihan tenaga administrai dan tenaga teknis keagamaan sesuai dengan wilayah kerja masing-masing. Berawal dari pola hidup ini muncul dan berkaitan dengan terwujudnya suatu desa adat di Bali. Dengan demikian suatu ciri khas desa adat di Bali minimal mempunyai tiga unsur pokok,yakni :wilayah, masyarakat dan tempat suci untu memuja Tuhan/Sang Hyang Widhi. Perpaduan tiga unsur itu secara harmonis sebagai landasan untuk terciptanya rasa hidup yang nyaman, tenteram, dan damai secara lahiriah maupun bathiniah. Ideologi Tri Hita Karana menegaskan bahwa siapapun yang hidup sebagai manusia memiliki modal dasar kebahagiaan dan kesejahterteraan yang sama. Dalam kaitannya dengan pengembangan kompetensi kejuruan untuk mewujudkan kesejahteraan dan kebahagiaanan seseorang harus menghayati modal Tri Hita Karana dan mengamalkan Tri Hita Karana. Manusia pendidikan kejuruan memerlukan fisik atau badan sebagai angga yang sehat dan bugar. Kompetensi kejuruan dikembangkan dengan melatih alat gerak (tangan, kaki, mulut), alat indria (telinga, mata, lidah, hidung, kulit), kemampuan berbicara (sabda), kemampuan bergerak (bayu), dan 
kemampuan berpikir (idep). Sebagai contoh pengembangan kompetensi menyolder memerlukan pelatihan keterampilan tangan dan pencermatan mata.

b. Pembinaan umat Hindu dalam meningkatkan sradha dan bhakti, memerlukan waktu yang cukup panjang untuk keberhasilan mencapai sasaran. Maka dibutuhkan kesabaran, strategi serta metode yang sesuai dengan kebutuhan masyarakat binaannya penyuluh, yakni masyarakat di Kabupaten Tabananan dalam membina umat, agar tumbnuh kesadaran dari dalam diri masing-masing untuk memahami, menghayati, dan menerapkannya dengan baik tentang implementasi ajaran Tri Hita Karana. Suatu kebudayaan merupakan milik bersama anggota suatu masyarakat atau suatu golongan sosial, yang penyebarannya kepada anggota-anggotanya dan pewarisannya kepada generasi berikutnya dilakukan melalui proses belajar dan dengan menggunakan simbol-simbol yang terwujud dalam bentuk yang terucapkan maupun yang tidak (termasuk juga berbagai peralatan yang dibuat oleh manusia). Dengan demikian, setiap anggota masyarakat mempunyai suatu pengetahuan mengenai kebudayaannya tersebut yang dapat tidak sama dengan anggota-anggota lainnya, disebabkan oleh pengalaman dan proses belajar yang berbeda dan karena lingkungan-lingkungan yang mereka hadapi tidak selamanya sama.

\section{Saran}

Untuk mendapatkan pelayanan yang terbaik bagi umat maka peningkatan mutu dari penyuluh dengan memberikan pembekalan yang lebih mendalam mengenai konsep Tri Hita Karana. Konsep Tri Hita Karana memiliki dasar-dasar yang esensial dari konsep kekerabatan di Bali. Untuk menjaga Bali tetap Ajeg, maju, damai, sejahtrera dan tetap eksis sepanjang zaman diharapkan adanya komitmen yang kuat dari semua komponen masyarakat Bali dengan berlandaskan konsep "Tri Hita Karana" untuk menjaga dan mengajegkan.

a. Balai Diklat Keagamaan Denpasar diharapkan untuk memberikan pendidikan dan Pelahinan kepada para Penyuluh Agama secara berkeinambungan, agar para penyuluh lebih percaya diri dan professional dalam melaksanakan tugas.

b. Para Penyuluh Agama Hindu agar lebih kooperatif mengisi diri bertanya kepada orang yang dianggap mampu dan mumpumi dibidangnya masing-masing.

\section{DAFTAR PUSTAKA}

Agastya, IBG, 2018. Warta Hindu Dharma edisi 499.

Burhan Bungin, Prof. Dr. H.M. S.Sos.M.Si, 2009, Sosiologi Komunikasi, Jakarta, Prenada Media Group.

Koentjaraningrat, 1980, Sejarah Antropologi I, Jakarta, Universitas Indonesia Koentjaraningrat, 1993, Manusia dan Kebudayaan di Indonesia, Jakarta, Jambatan

Moleong, L. J. 1999, Metodologi Penelitian Kualitatif, Bandung, Yudistira

Moleong, Lexy J. Prof. Dr. M.A., 2009, Metodologi Penelitian Kualitatif, Bandung, PT. Remaja Rosdakarya.

Mulyana, Deddy, 2001, Metodologi Penelitian Kualitatif, Paradigma Baru Ilmu Komunikasi dan Ilmu Sosial lainnya, Remaja, Rosdakarya, bandung. 
Mulyana, Deddy dan Salmon, (ed), 2007, Metode Penelitian Komulatif; Contoh-contoh Penelitian Kualitatif dengan Pendekatan Praktis; bandung, Remaja pedoman pelaksanaan tugas penyuluh agama Hindu, 2012:11

Poewadarminta, J, S., 1976, Kamus Umum Bahasa Indonesia, Jakarta, PN Balai Pustaka.

Prama, Gede, keindahan hidup Bali Pos, 3 Oktober 2018. Rosdakarya.

Raka Santeri, Kompas: 5 Desember 2017

Sugiyono, Prof.Dr., 2007 Memahami Penelitian Kualitatif, Bandung: Alfabeta

Sukardi, Prof.Ph.D., 2003, Metodologi Penelitian Pendidikan, Jakarta, Bumi Aksara

Tuner, Bryan S., 2006, Agama dan Teori Sosial, Yogyakarta, IRCiSoD

Titib, I Made, 2006, Teologi \& Simbol-Simbol Dalam Agama Hindu, Surabaya: Paramita

Tri Guna, I.B. Gede Yudha, 1997, Mobilitas Kelas, Konplik dan Penafsiran Kembali Simbolisme Masyarakat Hindu di Bali, bandung; Desertasi Universitas Padjadjaran.

Wiana, I Ketut, Drs. M.Ag., 2007, Tri Hita Karana Menurut Konsep Hindu, Surabaya, Paramita

Keppres No.87 Th.1999 tentang Rumpun Jabatan Fungsional 